12th International Conference on Industrial Engineering and Operations Management XXII Congreso de Ingeniería de Organización

Girona, Spain, July 12-13, 2018

\title{
Scrip Dividends and Share Buy-Back Strategies Based on Volatility
}

\begin{abstract}
The number of listed companies offering alternatives to cash dividends is increasing in Europe. Companies can reduce the cash outflows by giving shareholders the option to receive either shares or cash. Some investors favor scrip dividends due to the implicit free call option attached to the scrip distributions and recent studies confirm that the market does not react negatively, helping to reduce the agency problem. Additionally, companies can avoid dilution by repurchasing the shares offered in the scrip. Repurchase strategies using volatility and derivatives can guarantee a lower repurchase price, improving the capital ratios of the company and increasing Book Value of Equity per Share (BVPS).
\end{abstract}

Keywords: Scrip Dividends, Dividend Policies, Options, Share Buy-Back, Volatility, Agency Problem 


\section{Introduction}

Since the financial crisis of 2007, the use of optional stock dividends of scrip dividends has significantly increased among European companies, particularly in the Financial Institutions, Oil, Energy and Telecom sectors. Tax advantages for shareholders were the main driver in the past but changes in regulation in many countries eliminated such edge. Companies managers are reluctant to reduce dividends because of the potential market impact of such decision and dividends create a constraint for managers which conflicts with their objective of conserving cash and maintaining financial flexibility (Blau and Fuller 2008). Nevertheless, recent studies show that in present years, investors react favorably to scrip dividends (David and Ginglinger 2016) (Bessembinder and Zhang2015).

Script dividends are profit distributions to shareholders that include the option to receive new shares in lieu of cash at the shareholder discretion. At the ex-dividend date, the company gives the shareholder the right to elect to receive cash or shares for a short period of time that varies from one to four weeks typically. In some cases, the scrip trades in organized markets during the election period. Scrip dividends are elected by a majority of shareholders since they grant an additional call option with the shares during the period of optionality that can be monetized.

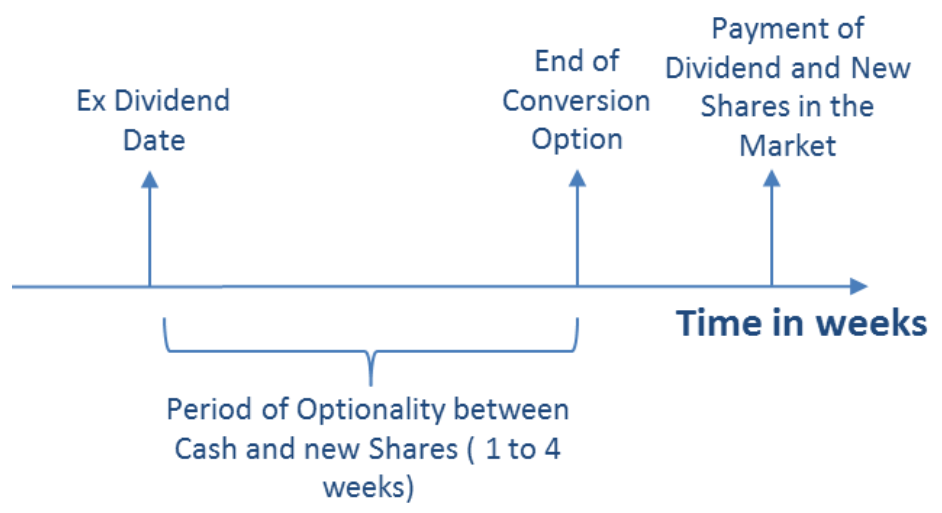

Figure 1. Scrip Dividends Time Frame

Cash dividends are one of the classical examples of the agency problem, where the conflict of interests between shareholders who want to maximize their equity value and who in general want to receive regular cash distributions and company managers who tend to prefer lower financial leverage, lower cost of debt and therefore reduced cash dividends.

Company managers have also the incentive to reduce the dilution for existing shareholders, and on several occasions in connection with scrip dividends, companies announce share repurchase plans. In this paper, we propose a share repurchase method that aims to reduce shareholder dilution and at the same time 
improves the capital ratio of the companies and increases net equity and shareholder value.

\section{Objectives}

This paper is the first document of an ongoing academic research that aims to study how and why companies use scrip dividends as a distribution method. The first objective is to study the free financial options attached to scrip dividends distributions and how the market values such options.

A second objective is to study is the repurchase methods that companies can use to avoid the dilution caused by scrip dividends and in particular one variation of the derivative instruments called accumulator share buy-back. Using market volatility accumulators can guarantee a minimum amount of shares repurchased at a price below the new issue price, which as a side effect improves the company's balance sheet and increases the equity value for shareholders.

\section{Methods}

This paper researches the scarce academic literature about scrip dividends to assess the size of the scrip dividend market, the motivation of managers to issue scrip dividends and the impact on share prices.

Using the vanilla options pricing model (Black and Scholes 1973), we assess the extra value granted to shareholders in the form of the options attached to scrip dividends.

Then using numerical option pricing methods, we calculate the cost of a strategy that can allow buying back shares at a lower price.

\section{Size of the Scrip Dividend Market in Europe}

According to Markit, the total value of dividends paid in scrip by European listed companies including UK listed companies has significantly increased over the last 10 years reaching Eur27bn in 2016. Banks, oil, and commodities companies are the sectors responsible for the growth of this form of shareholder remuneration. At least 39 major listed European companies paid scrip dividends in 2017. 


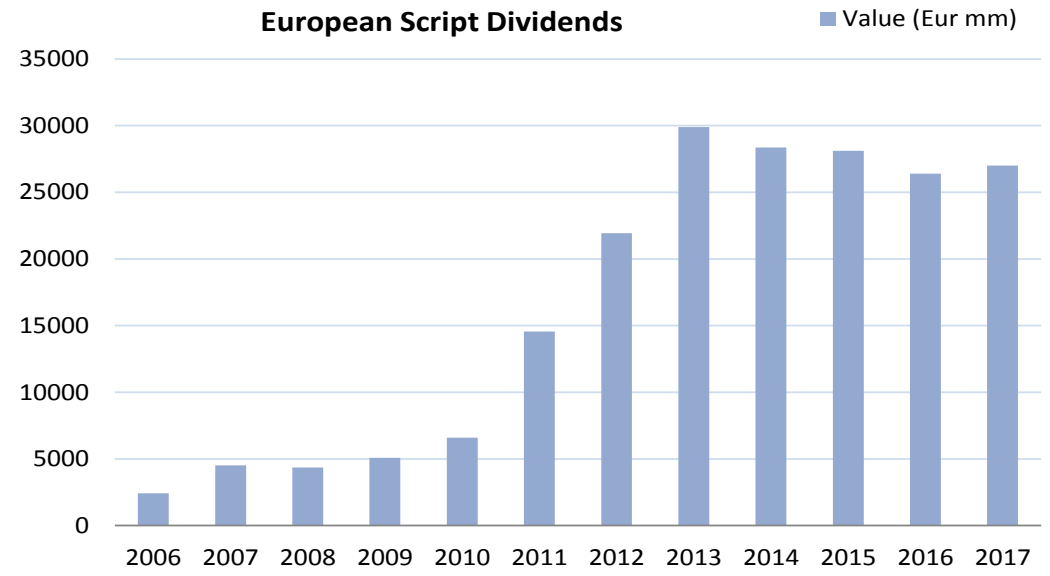

Figure 2. Amount of Scrit Dividends in Europe Source: Markit

\section{Motivations for Scrip Dividend Distributions}

Some companies prefer the scrip format for dividend distributions. Part of the reasons given by company managers are:

- Companies can offer greater optionality to their investors which can decide whether to receive cash or new shares and in some jurisdictions adapt taxation to the actual disposal of the shares

- Scrip dividends offer shareholders an implicit call option for some weeks since they can choose some weeks in advance whether to receive cash or a predefined number of shares at a strike price. Investors can monetize the time value and volatility of the implicit option by selling calls/volatility in the market.

- Scrip dividends can reduce the cost of cash in times of liquidity stress but at the same time increase the "agency problem" between managers and shareholders (Lasfer 1997). Managers tend to favor scrip dividends that avoid cash flows out of the company whereas shareholders in the classical theory prefer a cash distribution.

- Shareholders should be indifferent to the profit distribution policy of the company and therefore satisfied with scrip dividends in well run profitable companies since they increase retained earnings (Modigliani Miller 1961).

- Companies can avoid cash outlays by paying dividends in scrip format. Cash flows from financing activities are then maximizing allowing more free cash flow for capital investment and debt repayment. 
- Financial institutions can improve regulatory ratios paying distributions in shares instead of cash (ratios as Common Equity Tier 1, Liquidity Coverage ratio, Leverage Ratio).

- Firms can obtain equity at none or smaller discount than via rights issues or other equity offerings.

- It is a better solution than a dividend cut for cash-strapped companies.

\section{Implicit Options Attached to Scrip Distributions}

Thanks to the scrip dividends issuance procedure, company shareholders are implicitly granted options or warrants on the new issued shares. The mechanism of scrip dividends guarantees the existence of such options. The issue price is always set at the inception of the scrip dividend period, and during the election period, shareholders can take the cash dividend if the share price decreases below the issue price or share if the market price is higher the issue price. This optionality can be considered as an extra distribution to shareholders, and in fact, hedge funds and large shareholders position themselves to monetize such value.

The average maturity of the implicit options attached to the scrip dividends, the scrip election period, is 19 days in the European markets where this practice is common (David and Ginglinger 2016).

In some cases, companies offer scrip dividends at a discount compared to the prevailing market share prices, trying to entice existing shareholders to accept shares instead of cash. According to David and Ginglinger (2016), the average discount of the scrip shares compared to market prices the week before the exdividend date is $8.5 \%$.

Using the Black-Scholes continuous valuation model for equity options (Black Scholes 1973), the value of a European Call with a strike $K=91.5 \%$, maturing in 19 days, with average volatility of $30 \%, 3 \%$ dividend yield and market interest rates of $1 \%$ is close to $9.3 \%$, implying a implicit value of $8.5 \%$ and a time value of $0.8 \%$.

In some other cases, companies are not offering any discount to shareholders and the new shares are issued at the initial market price. But even in such case, the value of a European Call, strike at the money, maturing in 19 days, with an average volatility of $30 \%, 3 \%$ dividend yield and market interest rates of $1 \%$ is close to $3.2 \%$.

If the scrips fluctuate in the market, their price should follow the price of the listed options and shareholders could sell the scrip and pocket the extra value from the ex-dividend date. In other cases, shareholders can keep the scrip and sell the proportional number of call options and cash-in the premium. If investors cannot find a market for volatility, they still can lend the shares out to an investor willing to keep the call and receive the cash dividend plus the call value in the borrowing fee. 


\section{How to Reduce Dilution Linked to Scrip Dividends}

Companies can support their share price by announcing share buyback programs linked to the scrip dividend distributions. New shares in the market imply that company's future free cash flow will be distributed among more shares, meaning a higher dilution for the existing shareholders that have chosen not to receive shares.

To avoid shareholders' dilution, managers can raise new debt in the market and use that new cash to repurchase the new equity issued. But this solution deteriorates the leverage ratios of the company and again can reduce the future claim of shareholders.

Company managers can also issue other equity instruments that do not imply future profits distributions, like mandatory convertibles, to obtain that amount of cash. But due to market price oscillations, on both solutions, the amount cash needed for a later share repurchase is unknown in advance by company managers. Share price increases can result in a higher than forecasted financial indebtedness increase in the case of a debt issuance or an undesirable future increase in the outstanding shares at maturity, and again dilution in the case of mandatory convertibles. Both solutions imply uncertainty and a potential future reduction in the net shareholders' equity of the company. The question is if this can it be avoided?

\section{Share Repurchase Strategies with Volatility Instruments}

Companies can use repurchase strategies involving traded or over-the-counter (OTC) options with physical delivery can help companies to improve their capital base. Managers can sell volatility to derivatives dealers via sold puts to improve their repurchase call strike price and at the same time can purchase calls on a lower proportion. The higher sold volatility can help to reduce the call strike. Daily share repurchase accumulator strategies can smooth the delta and gamma factors of the options allowing dealers to trade higher call and put options notionals and therefore set the strike price on a single observation date or in a series of days coinciding with the scrip price set dates. Daily observation of the options can imply a higher number of shares repurchased, avoiding the European option single date observation effect and potentially increasing the number of shares repurchased.

The repurchase price or options strike must be set at the same time as the scrip dividend new issue price is announced. The strike $\mathrm{K}$ will be lower than the share price $\mathrm{S}$. The theoretical price of an accumulator can be calculated as:

$$
\text { Fair Value Accum }=\sum_{i=1}^{N} x * C_{u o}\left(K, H, T_{i}\right)-y * P_{u o}\left(K, H, T_{i}\right)
$$


Where $\mathrm{y}>\mathrm{x}, \mathrm{C}_{\mathrm{uо}}\left(\mathrm{K}, \mathrm{H}, \mathrm{T}_{\mathrm{i}}\right)$ is the price of a purchased physical delivery Call option with strike $\mathrm{K}$, maturity at $\mathrm{T}$ and knock out barrier at $\mathrm{H}$ and $\mathrm{P}_{\mathrm{uo}}\left(\mathrm{K}, \mathrm{H}, \mathrm{T}_{\mathrm{i}}\right)$ is the price of a sold physical delivery Put option with strike $\mathrm{K}$, maturity at $\mathrm{T}$ and knock out barrier at $\mathrm{H}$. The strike $\mathrm{K}$ of both options can be set below the spot and forward share price thanks to a higher volatility sold but the number of shares repurchased is unknown.

Calculations using numerical algorithms show that using daily observation Call and Put options, without KO barriers, and a $\mathrm{y} / \mathrm{x}$ factor of 2, the repurchase price can be set between $5 \%$ to $8 \%$ below spot prices, offsetting the share discount or improving retained earnings if no discount is offered.

\section{Accounting Impact of a Share Repurchase at a Lower Strike}

If a company can repurchase the shares offered in the scrip dividend at a lower price this will result in a net capital gain, reflected in new Net Retained Earnings balance sheet item and with no PnL impact. The structure is always more accretive for shareholders than standard cash repurchases and increases the Book Value Per Share.

Using the cost method for share repurchase accounting the cash spent for repurchasing the stock is lower than the estimated cash outflows for dividends, and the remaining amount is accounted under retained earnings.

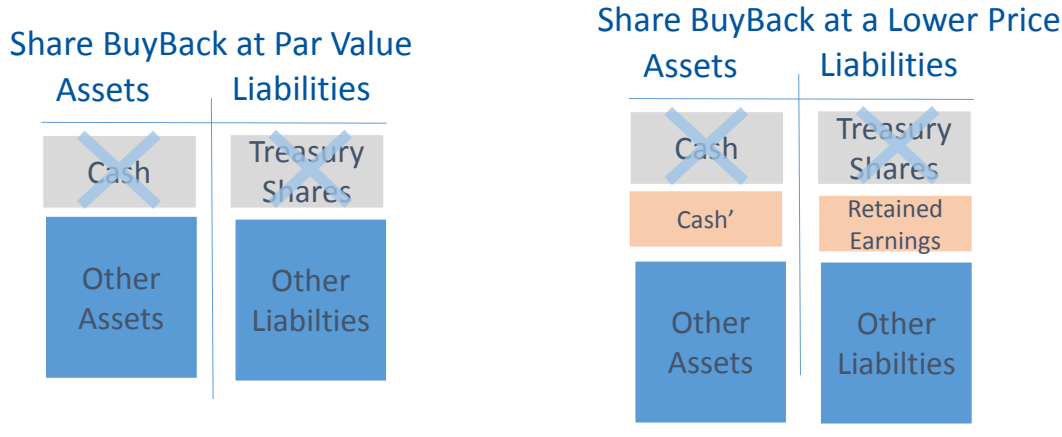

\section{Conclusions}

The agency problem between shareholders and management can be mitigated using scrip dividends distributions. Recent studies show that companies paying scrip dividends are committed to avoiding dividend cuts and the market does not react negatively to such announce. The present paper analyses the value of the options attached to scrip dividends that range between to $9.2 \%$ for the typical discount over the market price of the company shares to $3.2 \%$ for scrip dividends issued with no discount. Such discount levels attract both arbitrage funds and large investors that find more value to scrip dividends in the present cash-rich environment since scrip dividends offer shareholders an extra value that can be 
monetized. One method to reduce the dilution associated to scrip dividends is share buyback programs performed with the help of daily strips of leveraged derivatives or share repurchase accumulators that can effectively allow the repurchase of a limited number of shares below the new issue price, which improves the book value of the company.

\section{References}

Bessembinder, H; Zhang, F (2015). Predictable Corporate Distributions and Stock Returns. The Review of Financial Studies, Volume 28, 4, April 2015, 1199 1241

Black,F; Scholes,M (1973). The Pricing of Options and Corporate Liabilities. Journal of Political Economy, 81 pp.637-654

Blau, M.; Fuller, K (2008). Flexibility and Dividends. Journal of Corporate Finance, Volume 14, 2, April 2008, 133-152

David, T.; Ginglinger, E. (2016). When dividends is not bad news: The case of optional stock dividends. Journal of Corporate Finance 40 (2016) 174-191

Lasfer, A (1997). Scrip dividends. The management's view. European Financial Management, Vol 3, No.2, 1997, P237-249

Lasfer, A (1997). On the motivation for paying scrip dividends. European Financial Management, 26, 62-80

Miller, M. and Modigliani, F. (1961). Dividend policy, growth, and the valuation of shares. Journal of Business, vol. 34, pp. 411-433. 